\title{
Lembranças freireanas: reflexões docentes para pensar a formação de professores na Educação de Jovens e Adultos
}

\author{
Freirean memories: teachers' reflections to think about teacher education in \\ Youth and Adult Education
}

\author{
Renato Antônio Ribeiro ${ }^{1}$ \\ Simone Sendin Moreira Guimarães²
}

\begin{abstract}
Resumo
Este estudo apresenta reflexões advindas de entrevistas realizadas com professores e professoras da Educação de Jovens e Adultos (EJA) de escolas goianas quanto à potencialidade dos pressupostos freireanos como suporte ao processo formativo docente na modalidade. Neste movimento empírico, foi investigado se nas lembranças que emergem dos processos formativos dos docentes, Paulo Freire se fez/faz presente. A formação docente é uma preocupação presente ao longo de toda a obra freireana e diante dela cabe ponderarmos a necessidade de uma prática educativa que considere os contextos existenciais e a concretude dos estudantes. A partir das lembranças resgatadas junto aos docentes, foi possível perceber que o legado freireano se faz presente e pode dar suporte à prática docente na EJA. Vários conceitos-chave e/ou ideias freireanas emergiram nas lembranças resgatadas pelos docentes. Os resultados não sugerem plena apropriação teórica dos pressupostos freireanos e tampouco garantia de influência na prática educativa que exercem junto aos estudantes da EJA. Mas o legado teórico freireano, ao ser reinventado e recontextualizado nos espaços-tempo históricos, permite sustentar a formação de professores para a EJA a fim de fortalecê-la como uma modalidade que atenda aos interesses da classe trabalhadora estudante.
\end{abstract}

Palavras-chave: Paulo Freire. Educação de Adultos. Formação docente. Trabalhadores estudantes.

\section{Abstract}

This study presents reflections arising from interviews carried out with teachers of Youth and Adult Education (EJA) from schools in Goiás, regarding the potential of Freire's

\footnotetext{
${ }^{1}$ Doutorando no Programa de Pós-graduação em Educação em Ciências e Matemática (UFG); Mestre em Educação (UEG); Licenciado em Ciências Biológicas (UEG); Professor na EJA pela SEDUC-GO e em Instituições de Ensino Superior com disciplinas de Formação de Professores; Integrante do Grupo de Pesquisa Colligat: (re)pensando a formação de professores de Ciências e Biologia e do Fórum Goiano de Educação de Jovens e Adultos. E-mail: rhenato@gmail.com

2 Doutora em Educação Escolar (UNESP); Mestra em Educação (UNIMEP); Especialista em Educação Ambiental e Recursos Hídricos (USP-São Carlos); Licenciada em Ciências Biológicas (UNIMEP); Professora Associada I do Instituto de Ciências Biológicas (ICB) e do Programa de Pós-Graduação (Stricto Sensu) em Educação em Ciências e Matemática (PPGECM) da Universidade Federal de Goiás (UFG); Coordena o Grupo de Pesquisa Colligat - (re)pensando a formação de professores de ciências na natureza.

E-mail: sisendin@ufg.br ORCID: https://orcid.org/0000-0002-6559-2591
} 


\section{-Revista de Iniciação à Docência, v.6 , n. 2, 2021- \\ Publicação: dezembro, 2021 - ISSN 2525-4332}

assumptions as support for the teaching training process in the modality. In this empirical movement, it was investigated whether in the memories that emerge from the teachers' formative processes, Paulo Freire was/is present. Teacher training is a present concern throughout all of Freire's work and, in view of it, we must consider the need for an educational practice that considers the existential contexts and concreteness of students. From the memories rescued from the teachers, it was possible to see that the Freirean legacy is present and can support the teaching practice in EJA. Several key concepts and/or Freirean ideas emerged in the memories retrieved by the teachers. The results do not suggest full theoretical appropriation of Freire's assumptions, nor a guarantee of influence in the educational practice they exercise with EJA students. But Freire's theoretical legacy, when reinvented and recontextualized in historical spacetimes, allows for sustaining teacher education for EJA in order to strengthen it as a modality that meets the interests of the student working class.

Keywords: Paulo Freire. Adult Education. Teacher training. Student workers.

"Eu gostaria de ser lembrado como um sujeito que amou profundamente o mundo e as pessoas, os bichos, as árvores, as águas, a vida". (FREIRE, 2020a, p. 399) 3

\section{Considerações iniciais}

Em 2021 comemoramos o centenário de nascimento de Paulo Freire. Aproveitando a data, partimos, na epígrafe, de uma descrição feita pelo autor, em uma de suas últimas entrevistas, sobre como ele gostaria de ler lembrado. A síntese nos indica que ele gostaria de ser lembrado essencialmente como um sujeito que amou! Buscamos na "amorosidade" freireana pelo mundo e pelas "gentes" a necessidade de resgatar e relembrar seus pressupostos para tornar o mundo atual menos feio. Scocuglia (2021, p. 22) em publicação que celebra o centenário de Paulo Freire, afirma que "o pensamento político-pedagógico de Paulo Freire deve ser utilizado como contraponto viável à globalização hegemônica que impacta a cultura e educação brasileira e mundial nas últimas décadas". O autor ainda discorda da compreensão de que o pensamento freireano está desatualizado, pois "seus conceitos e propostas, [...] são atuais e prospectivos, [...], ou seja, um pensador e propositor da educação do futuro" (SCOCUGLIA, 2021, p. 22).

Ao empreender o resgate do referencial freireano, é necessário (re)contextualizálo e (re)aproximá-lo do contexto histórico no qual estamos inseridos. O Brasil e o mundo ainda estão diante dos efeitos devastadores de uma pandemia 4 que trouxe impactos nos

\footnotetext{
3 Declaração dada em entrevista para Edney Silvestre, em Abril de 1997 em Nova Iorque e publicada posteriormente em Pedagogia da tolerância (FREIRE, 2020a).

${ }^{4}$ A pandemia de COVID-19, causada pelo Sars-CoV-2, um tipo de coronavírus, assola o mundo desde fins de 2019, com as primeiras infecções identificadas na China, de onde se espalhou para todos os países, já tendo matado mais de 560 mil pessoas só no Brasil (dados de Agosto/2021).
} 


\section{-Revista de Iniciação à Docência, v.6 , n. 2, 2021- \\ Publicação: dezembro, 2021 - ISSN 2525-4332}

mais variados aspectos da existência humana. A educação escolar, inclusive, foi duramente afetada, tendo acentuado as desigualdades de acesso/permanência à escolarização na sociedade5. Ainda neste contexto pandêmico, a educação pública no Brasil sofre um desmonte sem precedentes na história recente. Estamos diante de um cenário em que cortes orçamentários para a educação são frequentes ${ }^{6}$ e uma guerra ideológica na luta por uma escola "neutra" se instalou7, inclusive com aversão explícita do governo federal a Paulo Freire ${ }^{8}$.

O panorama que se vislumbra é desafiador, forjado na imprevisibilidade e um tanto quanto impregnado de "feiura" na percepção freireana, mas que não pode se precipitar na desesperança. Neste sentido, Freire (1995, n.p) afirma: “um dia este país encontra consigo mesmo e fica menos feio do que hoje. Este país não nasceu feio e nem nasceu para ser feio. Ninguém nasceu para ser feio. A gente vira feio ou vira bonito na medida em que a gente luta com alegria e com esperança". Assim, empreendendo uma releitura do legado freireano no quadro atual e esperançosos de que a "feiura" do contexto no qual nos encontramos pode ser superada e transformada, concordamos com a perspectiva freireana acerca da contribuição da educação escolar neste movimento, mas cientes de que "se a educação sozinha não transforma a sociedade, sem ela tampouco a sociedade muda" (FREIRE, 2014 p. 77). Partilhamos ainda a acepção freireana quanto à indissociável relação entre política e prática educativa, pois a ilusória neutralidade e apoliticidade da educação "não é outra coisa senão a maneira manhosa com que se procura esconder a opção [em favor da opressão]” (FREIRE, 2011, p. 155).

Saviani (2020) ao caracterizar o desmonte da educação nacional agudizado pelo contexto pandêmico assinala que estamos imersos numa crise política, econômica, social e sanitária de grandes proporções, com ataques à educação pública e tentativas de efetivar sua privatização, convertendo-a em mercadoria, bem como a desqualificação e

\footnotetext{
${ }^{5}$ Durante a pandemia de COVID-19 no Brasil, as instituições escolares de educação básica tiveram suas aulas presenciais suspensas, sendo substituídas pelos regimes de "aulas remotas", tendo suporte em meios tecnológicos digitais ou não. Os estudantes se viram envoltos com ferramentas tecnológicas que pouco dominam e/ou sequer tem acesso.

${ }^{6}$ Segundo o $6^{\circ}$ Relatório Bimestral Execução Orçamentária do Ministério da Educação (MEC) elaborado pela organização "Todos pela educação" e divulgado em Fevereiro de 2021, o MEC concluiu o exercício de 2020 com o menor orçamento e execução da década para as despesas com Educação Básica, o que indica um contrassenso pelo contexto pandêmico diante das necessidades educacionais que passaram por adaptação à nova realidade de ensino remoto ou híbrido. Disponível em: https://todospelaeducacao.org.br/wordpress/wp-content/uploads/2021/02/6\%C2\%Bo-Relatorio-Bimestral-daExecucao-Orcamentaria-do-MEC.pdf

7 Quanto à suposta "neutralidade" da instituição escolar, surge em 2004 o "Movimento Escola sem Partido" que defende a descontaminação político-ideológica nas escolas. O movimento avança a partir de 2014 quando se propõem diferentes Projetos de Lei (PL) com este contexto. O mais recente é o PL 246/2019 que institui o "Programa Escola sem Partido", projeto ainda em tramitação na Câmara dos deputados. Disponível em: https://www.camara.leg.br/proposicoesWeb/fichadetramitacao?idProposicao=2190752

${ }^{8}$ No governo da atual presidência da república brasileira (2019-2022), Jair Bolsonaro é veementemente contra os pressupostos freireanos, criticando insistentemente todo seu legado na educação brasileira. Chamando Paulo Freire de "energúmeno" em dada ocasião, o atual presidente atribui à sua herança acadêmica o fracasso educacional brasileiro ao longo da história.
} 


\section{-Revista de Iniciação à Docência, v.6 , n. 2, 2021- \\ Publicação: dezembro, 2021 - ISSN 2525-4332}

perseguição à atividade profissional docente, promovendo um suicídio da democracia brasileira. Em face dessa perspectiva, Freire (2020b) nos convoca a lutar incansavelmente pela escola pública, buscando fazê-la melhor e "mudando sua cara". Nesta luta e defesa da escola pública, Paulo Freire ainda demarca a importância da formação dos profissionais docentes: "estou convencido da importância, da urgência da democratização da escola pública, da formação permanente de seus educadores e educadoras [...]. Formação permanente, científica, a que não falte sobretudo o gosto das práticas democráticas [...]" (FREIRE, 2011, p. 32).

A formação docente é uma preocupação presente ao longo de toda a obra freireana, mas sua relevância se aprofunda e torna-se mais sistematizada nas obras "Medo e ousadia - o cotidiano do professor" (de l986), "A educação na cidade" (de 1991), "Professora sim, tia não: cartas a quem ousa ensinar" (de 1993), e "Pedagogia da autonomia: saberes necessários à prática educativa” (de 1996), todas escritas já após seu retorno ao Brasil em 1980, depois do exílio de 15 anos. Para Saul e Saul (2016, p. 24) Paulo Freire é um "referencial singular que articula as dimensões antropológica, ético-política, filosófica, epistemológica, metodológica e pedagógica e se mostra como um caminho possível para responder aos desafios da formação docente".

Tomamos aqui a formação de professores, sob a ótica freireana, como um elemento contribuinte no processo de transformação da sociedade que passa pela educação e que ascende a um mundo "menos feio". Diante desta condição, este estudo se propõe a apresentar reflexões advindas de entrevistas com professores e professoras da Educação de Jovens e Adultos (EJA) de instituições escolares goianas quanto à potencialidade dos pressupostos freireanos darem suporte ao processo formativo docente na modalidade. Para Machado (2008) ainda existe uma "difícil travessia" no campo da formação de professores para atuação na EJA, a qual é desmerecida e/ou ignorada nos cursos de licenciatura e consequentemente desconsiderando a realidade concreta dos educandos e educandas. Nesta mesma interpretação, Paranhos et al. (2020, p. 3) afirmam que "é importante que as escolas de EJA estejam próximas ao seu público demandante. [...] É premente a demanda de se pensar os espaços escolares que sejam atinentes à identidade do público da EJA".

De acordo com Soares, Giovanetti e Gomes (2011, p. 7) a EJA "é um campo carregado de complexidades que carece de definições e posicionamentos claros". Em vista disso, concebemos aqui a EJA como uma modalidade educacional que restabelece o direito à educação, negado à classe trabalhadora estudante, que se constitui de adolescentes, jovens, adultos e idosos. Ao demarcar e sublinhar tal concepção, entendemos também que o resgate deste direito possibilita uma educação que se assenta como "um importante instrumento para que o trabalhador consiga não apenas ter acesso aos conhecimentos, mas que, a partir deles, possa controlar o processo de produção e reprodução dos conhecimentos científicos e técnicos envolvidos no processo produtivo" (LOMBARDI, 2010, p. 235). 


\section{-Revista de Iniciação à Docência, v.6 , n. 2, 2021- \\ Publicação: dezembro, 2021 - ISSN 2525-4332}

Se admitirmos que os estudantes da EJA, os quais compõem a classe trabalhadora, estão unidos por um corte de classe, logicamente estão submetidos a uma condição de opressão na sociedade capitalista. Perante isto, cabe ponderarmos a necessidade de uma prática educativa que reflita sobre seus contextos existenciais e sua concretude, ou seja, uma "pedagogia dele". Em sua Pedagogia do Oprimido, Freire atesta que "será na sua convivência com os oprimidos, sabendo-se também um deles [...], que poderá compreender as formas de ser e comportar-se dos oprimidos, que refletem, em momentos diversos, a estrutura da dominação" (FREIRE, 2013, p. 67). Assim, buscamos em Freire um referencial que sustente a formação de professores para a EJA e que pondere a realidade concreta da classe trabalhadora estudante presente na modalidade.

\section{Construção Metodológica}

Tendo Paulo Freire como um referencial teórico-filosófico, a presente pesquisa iniciou-se com o movimento de revisão bibliográfica de sua obra, buscando elementos em que o autor tece reflexões sobre a formação docente, presentes e entrelaçadas com vários de seus conceitos-chave, em especial a relação teoria-prática. Posteriormente o movimento de pesquisa partiu para uma fase empírica junto a professores e professoras de instituições públicas que oferecem prioritariamente a EJA no estado de Goiás, os CEJAs (Centro de Educação para Jovens e Adultos). São sete instituições no estado: duas em Goiânia, uma em Anápolis, uma em Catalão, uma em Caldas Novas, uma em Iporá e uma em Aragarças. Esta fase de investigação contempla uma pesquisa mais ampla em nível de doutorado desenvolvida pelo primeiro autor, a qual ainda está em andamento 9 .

Nestas instituições foram realizadas entrevistas semiestruturadas com professores e professoras de biologia $^{10}$ que ministram aulas na Terceira Etapa da EJA, que corresponde ao Ensino Médio da educação básica, totalizando 12 docentes, sendo 4 professores e 8 professoras. A Secretaria de Estado da Educação do estado de Goiás (SEDUC) via Superintendência de Modalidades e Temáticas Especiais e Gerência de Educação de Jovens e Adultos deu anuência à pesquisa e forneceu a listagem dos CEJAs em funcionamento no estado, bem como contatos telefônicos dos(as) gestores(as) das instituições. Estes foram contatados e indicaram os professores de biologia aptos a participarem da pesquisa. Os professores e professoras foram contatados via mensagem de texto/áudio pelo aplicativo Whatsapp ${ }^{\circledR}$ e as entrevistas foram agendadas e realizadas pela plataforma Google Meet ${ }^{\circledR}$ em virtude da situação de Pandemia de COVID-19 a partir

\footnotetext{
9 Considerando os pressupostos freireanos, esta pesquisa mais ampla objetiva identificar os sujeitos envolvidos na construção do currículo de biologia na EJA oferecida na rede estadual de educação do estado de Goiás, apontando o diálogo que se estabelece neste processo. A entrevista completa com os professores e professoras, que integra a tese, possui 20 questões.

10 Justifica-se a exclusiva inclusão de professores e professoras de biologia pela pesquisa mais ampla de doutorado que investiga especificamente o currículo de biologia na EJA do estado de Goiás.
} 


\section{-Revista de Iniciação à Docência, v.6 , n. 2, 2021- \\ Publicação: dezembro, 2021 - ISSN 2525-4332}

de 2020 no país, o que impediu a realização das entrevistas na forma presencial ${ }^{11}$. Os participantes da pesquisa foram informados das questões éticas estabelecidas para a pesquisa científica ${ }^{12}$, tendo dado seu consentimento no Termo de Consentimento Livre e Esclarecido.

No presente recorte nos ocupamos em promover reflexões sobre a formação docente na EJA pautada pelo referencial freireano e partindo do discurso dos professores e professoras entrevistados. Tais problematizações originam-se a partir de um questionamento específico na entrevista: "Você conhece / leu / estudou Paulo Freire ao longo de sua formação acadêmica? Em caso afirmativo, poderia mencionar alguma ideia do autor que lhe chama mais atenção?" A intenção deste questionamento se constituiu em promover um momento de reflexão para os professores e professoras quanto à sua própria formação profissional, investigando se em suas lembranças Paulo Freire se fez/faz presente. De forma quase unânime, nas respostas dos entrevistados emergiram diferentes conceitos-chave e/ou pressupostos que de fato estão presentes no legado teórico freireano. Assim, o referencial teórico-epistemológico-metodológico de Paulo Freire orientou a análise dos dados coletados e as reflexões resultantes deste movimento de pesquisa acerca das "lembranças freireanas" que os professores e professoras carregam de/em sua formação profissional para a atuação na EJA, as quais são apresentadas na próxima seção.

\section{“Você conhece Paulo Freire?": reflexões docentes e a formação de professores na EJA}

A partir da realidade concreta de que a EJA atende à classe trabalhadora estudante que teve o direito à educação negado, cabe frisarmos que a modalidade “como um campo político de formação e de investigação, está irremediavelmente comprometida com a educação das camadas populares e com a superação das diferentes formas de exclusão e discriminação existentes em nossa sociedade" (SOARES; GIOVANETTI; GOMES, 2011, p. 8).

Tendo os educandos e educandas trabalhadores como a centralidade da prática educativa na EJA, defendemos um projeto formativo na modalidade que permita às massas populares inserirem-se criticamente na realidade, saindo de um estado de "imersão" e impotência em face da realidade opressora e possibilitando-as transpor suas "situações-limite"13 (FREIRE, 2013). Para isto, consideramos que o papel docente é um elemento importante e imprescindível, mas não como uma relação de submissão entre

\footnotetext{
${ }^{11}$ Devido à Pandemia de COVID-19, as instituições escolares públicas no estado de Goiás aderiram ao regime especial de aulas não presenciais (REANP) durante todo o ano de 2020 e início de 2021.

${ }^{12}$ Pesquisa aprovada no Comitê de Ética em Pesquisa/CEP-UFG (Número do Parecer: 4.277.192).

${ }^{13}$ É um conceito que perpassa toda obra freireana e que se constitui como uma postura fatalista e submissa do indivíduo diante de um fato e/ou condição de sua existência, sendo incapaz de transpor e/ou agir para transformar tal realidade.
} 


\section{-Revista de Iniciação à Docência, v.6 , n. 2, 2021- \\ Publicação: dezembro, 2021 - ISSN 2525-4332}

educador-educando, na qual "o educador é o que educa; os educandos, os que são educados; o educador é o que sabe; os educandos, os que não sabem" (FREIRE, 2013, p. 82).

Propõe-se a prática da "dodiscência", conceito explicitado por Paulo Freire em Pedagogia da Autonomia, que remete a uma relação simbiótica, indicotomizável e permanente no processo de ensino-aprendizagem, pois “em que se ensina e se aprende o conhecimento já existente e o em que se trabalha a produção do conhecimento ainda não existente" (FREIRE, 2020c, p. 30). Essa relação concomitante e interseccionada compõe a radicalidade da proposta de educação libertadora freireana, constituindo "uma situação na qual tanto os professores como os alunos devem ser os que aprendem; devem ser os sujeitos cognitivos, apesar de serem diferentes" (FREIRE; SHOR, 1987, p. 46). Esta postura de "horizontalidade" entre educando(a) - educador(a) não se forja "inatamente" na atividade profissional docente, mesmo porque Freire já alertava que "ninguém começa a ser educador numa certa terça-feira às quatro da tarde. Ninguém nasce educador ou marcado para ser educador. A gente se faz educador, a gente se forma, como educador, permanentemente, na prática e na reflexão sobre a prática" (FREIRE, 1991, p. 58). Assim, ponderamos ser um processo, constante e permanente, o movimento de formação docente que considere tal perspectiva freireana e que possibilite à modalidade EJA dispor de professores e professoras que assumam o compromisso político com os educandos e educandas que nela estão inseridos.

Embora consideremos apropriado ter Paulo Freire e seu legado teórico como um referencial válido e legítimo no campo da Educação de Jovens e Adultos, especificamente para a formação de professores para atuação na modalidade, cabe reiterar que não assumimos a postura de "obrigatoriedade" de seguir seus pressupostos como uma espécie de "sacerdócio teórico" ou um "messias" que responde a todas as demandas presentes na EJA. Contrário à "cultura da exacerbação de fartos narcisismos acadêmicos" Ghiggi (2010, p. 112) aponta que de fato Paulo Freire é uma referência teórica válida na atualidade, pois "ele faz a denúncia, problematiza e anuncia o tempo que pode (e deve!) vir, porque é um tempo histórico", mas alerta para a disseminação e apropriação de "agendas freireanas despolitizadas" em nosso país e provoca: "vivemos perigosamente momentos que podem transformar Freire em mais um modismo. [...] Freire perde quando permitimos que seu texto seja absorvido por leituras licenciosas; perde pelas formas despolitizadas como seu texto é reconstituído" (GHIGGI, 2010, p. 114-115). Nesta mesma direção, Esquinsani (2016), analisando a disseminação do legado de Paulo Freire na formação inicial de professores sinaliza a transformação do autor num "ícone", personificado num "mito" e uma "figura certa" nos debates em torno da formação docente após o falecimento dele em 1997. Observa-se então:

o crescimento das ideias freireanas e, como consequência, a tentativa de uso inadvertido, por parte de alguns - dos aportes de Paulo Freire para explicar todas as situações educacionais vivenciadas no início do século XXI. Ser 'freireano' era moda [em fins da década de 1990], quase uma profissão de fé. Anacrônicos eram 


\section{-Revista de Iniciação à Docência, v.6 , n. 2, 2021- Publicação: dezembro, 2021 - ISSN 2525-4332}

todos os demais que não utilizavam [as ideias do educador em seus discursos] (ESQUINSANI, 2016, p. 234).

A autora ainda reforça em sua pesquisa uma apropriação dos pressupostos freireanos que vai desde o dogmatismo, passando pelo "achismo e simplificação teórica" até o desconhecimento, esquecimento e/ou esvaziamento do pensamento de Freire, tornando-a uma teoria inerte diante da formação docente e reduzida a uma atividade de "citação" de "frases de efeito" do autor (ESQUINSANI, 2016). Diante destes alertas, frisamos a real necessidade de não apenas tomar Paulo Freire para pensar a formação de professores na EJA como um dogma ou caminho teórico inquestionável, mas considerar sua produção teórica e suas experiências com educação de adultos desde suas práticas de alfabetização no nordeste brasileiro na década de 1950-60 e ser capaz de ressignificar seus pressupostos diante do contexto atual brasileiro, mais especificamente na formação docente na EJA.

Paulo Freire já nos despertava para esta prerrogativa: "a única maneira que alguém tem de aplicar, no seu contexto, alguma das proposições que fiz é exatamente refazer-me, quer dizer, não seguir-me" (FREIRE; FAUNDEZ, 2019, p. 60). Ao não simplesmente "aplicá-lo" teoricamente para refletir sobre a formação docente na EJA, permite-se que seus pressupostos teóricos "iluminem" o objeto de nossa reflexão, pois "a teorização deve regressar à prática [...] como uma nova luz. [...] A teoria se faz guia para a ação transformadora do real” (FREIRE; BETTO, 1985, p. 77).

Assim, tomando Paulo Freire como uma "possibilidade teórica" válida e legítima que sustente as discussões em torno da formação de professores na EJA, avancemos neste ponto. De acordo com Paranhos et al. (2020, p. 4) "os marcos regimentais não têm garantido a inserção da EJA nos cursos de formação inicial de professores", afirmando ainda que "as pesquisas e os movimentos sociais, há mais de vinte anos, têm explicitado a demanda da EJA nas licenciaturas". De fato, o último marco regimental quanto à formação de professores no Brasil que definiu as Diretrizes Curriculares Nacionais para a Formação Inicial de Professores para a Educação Básica data de 2019 e propõe um "alinhamento" à Base Nacional Comum Curricular (BNCC), também recém-implantada. Porém, tanto a BNCC (BRASIL, 2017) quanto as novas diretrizes de formação de professores (BRASIL, 2019) desconsideram a EJA em suas especificidades. As diretrizes de formação de professores de 2019 nem sequer cita e demarca a EJA claramente, mencionando apenas que a formação docente tem como princípio atender a todas as modalidades e citando o atendimento a jovens e adultos (BRASIL, 2019). Também no documento da BNCC, a Educação de Jovens e Adultos está restrita à uma citação solitária numa linha, de uma única página, junto a outras modalidades (BRASIL, 2017).

As políticas em torno da formação de professores para a atuação na EJA corroboram uma "marginalização" da modalidade no contexto atual. Mas tal "opção" em não considerar as especificidades da EJA nos documentos está a favor de alguém e de algo, que não os interesses da classe trabalhadora estudante inserida na modalidade. 


\section{-Revista de Iniciação à Docência, v.6 , n. 2, 2021- \\ Publicação: dezembro, 2021 - ISSN 2525-4332}

Para Freire (2016, p. 124-125) "se a marginalidade não é uma opção, o homem marginalizado tem sido excluído do sistema social e é mantido fora dele, quer dizer, é um objeto de violência. [...] Não são homens à margem da estrutura, mas homens oprimidos no interior da mesma estrutura". Logo, concordando com Freire quanto à perspectiva de exclusão em detrimento de marginalização, entendemos que excluir e/ou não demarcar claramente a EJA nas diretrizes e demais documentos que norteiam a formação de professores na modalidade tem um significado muito claro: desprezar a realidade concreta dos estudantes e mantê-los sob condições de opressão, dominação e alienação na sociedade capitalista.

Frente à "exclusão" da EJA nas políticas educacionais de formação de professores, cabe considerarmos de que forma tal movimento excludente influencia no discurso da “qualidade da educação”. Segundo Soares (2006, p. 9) “entre tantas questões discutidas na EJA, a formação vem sendo colocada como uma das estratégias para se avançar na qualidade da educação". Mas que "qualidade" da educação? Qualidade a serviço de quem? Do que? Para que? Freire (2020b, p. 48) alerta-nos para a necessidade de "nos indagar em torno de que qualidade estamos falando". Para ele, há "qualidades e qualidades" e tais parâmetros não podem ser "valorados" da mesma forma frente à realidade concreta de dominantes e dominados, pois:

\footnotetext{
Assim como é impossível pensar a educação de forma neutra, é impossível igualmente pensar a valoração que se dê a ela neutralmente. [...] Valores, são vistas de ângulos diferentes, em função de interesses de classes ou de grupos. [...] Educação e qualidade são sempre uma questão política, fora de cuja reflexão, de cuja compreensão não nos é possível entender nem uma nem outra (FREIRE, 2020b, p. 47; 50).
}

Portanto, a relação entre educação e qualidade em Paulo Freire coaduna a perspectiva de uma escola de qualidade socialmente referenciada (DOURADO; OLIVEIRA, 2009), na qual não se pode adotar um padrão único de qualidade, cujo conceito é polissêmico. Para pensar em qualidade educacional na EJA cabe reafirmarmos a quem ela atende pautados em Arroyo (2011), que percebe uma reconfiguração da EJA na atualidade, propondo a superação da visão do estudante como um sujeito com carências e lacunas de escolarização apenas, estando a modalidade restrita a uma segunda oportunidade de escolarização. Segundo o autor, é necessário ver os estudantes "em suas trajetórias humanas" (p. 24), compondo "identidades coletivas", reconhecendo sua vulnerabilidade histórica e sua constituição como indivíduos que "carregam trajetórias perversas de exclusão social, vivenciam trajetórias de negação de direitos mais básicos à vida, ao afeto, à alimentação, à moradia, ao trabalho e à sobrevivência" (ARROYO, 2011, p. 24). Enfim, são das camadas populares e compõem a classe trabalhadora. Consequentemente, falar da "qualidade da educação" e sua relação com o processo de formação docente implica considerar dimensões socioeconômicas e culturais dos educandos e educandas da EJA, bem como à superação das condições de desigualdade às quais estão submetidos. 
Fizemos até aqui considerações acerca da relação entre formação docente na EJA e a centralidade da prática educativa nos sujeitos educandos e educandas, pautados pelos pressupostos de Paulo Freire. Como aprofundamento desta reflexão, vejamos como os professores das sete instituições escolares goianas que oferecem exclusivamente a EJA recobraram lembranças freireanas no seu percurso formativo na docência a partir das entrevistas realizadas ${ }^{14}$. Os depoentes estão identificados pela sequência das entrevistas (P01, P02...P12), seguidos da identidade de gênero ( $M$ : masculino / F: feminino). Alguns termos e/ou expressões estão sublinhadas a fim de demarcar conceitos-chave e/ou ideias pertencentes à construção teórica de Paulo Freire.

Ratificamos que nas lembranças dos momentos de formação docente recuperadas pelos professores e professoras da EJA entrevistados, Paulo Freire está "vivo" e presente, pois quase a totalidade dos professores (exceto P12) conseguiu recuperar na memória e mencionar ao menos um conceito-chave da obra do autor ou um pensamento radicado em suas ideias. A partir desta constatação, evidencia-se que o referencial freireano perpassa (ou perpassou) algum momento da formação destes professores e professoras da EJA, seja na formação inicial, seja na formação continuada. Talvez esta lembrança possa estar presente na realização dos próprios cursos de graduação e/ou pós-graduação, bem como pela busca individual de cada professor(a) na leitura de Paulo Freire.

Nas lembranças que recuperaram, alguns docentes (P01, P11 e P12) mencionaram o contexto político atual que tem aversão às ideias freireanas, conforme já explicitado neste trabalho. Enfatizaram como as ideias do autor, no contexto da educação brasileira, são objetos de crítica, desprezo e "demonização" segundo a ótica do governo federal atual:

[...] Então a questão dessa educação libertadora, da participação do aluno na construção do seu aprendizado, [...] a gente fica até entristecido com [...] o pensamento das pessoas que estão governando nosso país, sobre o desprezo, a falta de respeito, a demonização deste grande colaborador para educação do Brasil. Então quando fala de Paulo Freire, eu lembro da escola que todo mundo sonha, com a construção do indivíduo e ele participa nessa construção e não simplesmente enfiando um conteúdo na pessoa e onde não tem direito de conversar, porque tem que correr com o conteúdo. Às vezes suas ideias saem um pouco fora daquilo que está sendo ensinado e as pessoas não procuram escutá-lo. [...] Paulo Freire é uma escola que vai trazer muito mais crescimento para o aluno, na sua formação como pessoa crítica, com pensamento mais arejado [...] [P01 - M]

[...] lembro de algumas ideias dele né sobre aprendizagem. [...] Mas eu sou tradicional, o Paulo Freire ele revolucionou, eu respeito muito, mas ele trabalhava muito com alfabetização não é isso? [...] eu acho muito livre; ele tem essa teoria que aprendizagem, ela tem que ser muito livre [...] Ele propôs a um tempo atrás uma revolução no ensino e que hoje ele está sendo muito criticado por isso. [...] Lógico que ele tem um valor enorme, uma importância muito

\footnotetext{
${ }^{14}$ A partir do pressuposto freireano de respeito à linguagem, optamos por transcrever fielmente a fala/escrita dos sujeitos entrevistados, não efetuando correção ortográfica e/ou gramatical de nenhuma natureza em suas "falas".
} 


\section{-Revista de Iniciação à Docência, v.6 , n. 2, 2021- \\ Publicação: dezembro, 2021 - ISSN 2525-4332}

grande, mas aquele radicalismo também eu acho que o radicalismo total não existe, mas liberdade total também não existe. E agora, com o nosso governo Bolsonaro, ele veio para destruir Paulo Freire, destruir todas as ideias e acho que ele não agrada não. $O$ ensino tradicional para mim eu acho que aquele que o aluno aprende e o professor ensina e aprende também, não quer dizer que tem que ficar sentadinho na cadeira, não pode usar tecnologia, não é isso que eu tô querendo dizer, eu tô querendo dizer que a gente tem que ter uma rotina de estudo, participação do aluno, uma certa disciplina, Não dá para ser muito à vontade [...]

[P11 - F]

[...] pra te falar a verdade, a única coisa que eu sei de Paulo Freire, é que às vezes eu vejo alguma chamada contra na mídia, na internet e me irrita. Mas assim, eu não me lembro de nada nesse momento. [P12 - F]

Interessante constatar que Paulo Freire já se adiantara em vários momentos de sua obra quanto às críticas que recebia. Mas apesar da humildade com que as recebia, não se furtava de uma "justa raiva” pela deturpação de alguns de seus pressupostos. Em Política e educação, publicado em 1993, Paulo Freire dedica um capítulo específico a esta questão - "Do direito de criticar - do dever de não mentir ao criticar". O autor alerta que não se pode tecer críticas a certo pensamento a partir de "ouvir dizer" sobre ele, sendo exigido conhecê-lo a fundo: "não é ético nem rigoroso criticar o que não conhecemos" (FREIRE, 2020b, p. 70). Freire ainda se mostra indignado com a "raiva mentirosa" em torno de um pensamento: "Que temos o direito de ter raiva de gentes não há dúvida. É óbvio também. O direito que tenho de ter raiva de Maria ou de José não pode se alongar, porém, ao de mentir em torno dele ou dela. [...] Não posso distorcer o pensamento que estudo e crítico" (FREIRE, 202ob, p. 71; 73).

Diante desta indignação de Freire, cabe corroborar sua postura frente à distorção de suas ideias. Tomemos o exemplo da fala de P11, que "acha" o autor muito livre e defensor de uma "liberdade total". Paulo Freire jamais coadunou essa perspectiva. Pelo contrário: o autor defende uma intrínseca relação de equilíbrio entre autoridade (não autoritarismo) e liberdade. Em "Pedagogia da Autonomia", o autor pondera que "não resolvemos bem, ainda, entre nós, a tensão que a contradição autoridade-liberdade nos coloca e confundimos quase sempre autoridade com autoritarismo, licença com liberdade (FREIRE, 2020c, p. 60). Na mesma obra ele afirma que "ensinar exige liberdade e autoridade. [...] A liberdade sem limite é tão negada quanto a liberdade asfixiada ou castrada" (p. 102-103).

Já em “Medo e ousadia - o cotidiano do professor", Freire e Shor (1987, p.) reiteram: "sem autoridade, é muito difícil modelar a liberdade dos estudantes. A liberdade precisa de autoridade para se tornar livre. É um paradoxo, mas é verdade". Logo, o discurso de P11 é claramente deturpado quanto à ideia de liberdade e autoridade em Paulo Freire, atribuindo a ele uma liberdade incondicional, que Freire jamais defendeu, além de não relacionar a ele a ideia de autoridade e disciplina. Em "Professora, sim; tia, não" o autor reforça que "não há disciplina no imobilismo, quer dizer, na autoridade indiferente, fria, distante, que entrega à liberdade os destinos de si mesma" (FREIRE, 
2012, p. 190). Assim, segundo os pressupostos freireanos existe a tensão permanente entre liberdade-autoridade, sendo também pautada pela rigorosidade e pela disciplina.

Ainda quanto a estes elementos, temos:

[...] seria essa de ensinar com amor, você colocar amor naquilo que você faz; eu sempre fiz isso e os alunos percebem isso. [...] ]eu falo para eles: "olha eu estou aqui por vocês, o que me importa é o aprendizado de vocês, o que tiver ao meu alcance de fazer por vocês eu vou fazer como professora". Então eu acho isso importante na construção da relação professor-aluno, que é uma coisa que Paulo Freire também menciona nos seus escritos, ter essa relação uma relação harmoniosa, não uma relação de superioridade, uma relação de imposição. Ah eu sei você não sabe. Então você fica aí na sua. Não, não é por aí! eu não enxergo dessa forma. [...] E

se você já tem uma relação harmoniosa, uma relação tranquila, você ajuda o aluno na aprendizagem dele. $\mathrm{E}$ ao contrário disso quando você tem uma antipatia, quando você tem um ambiente hostil, né uma relação como se fosse uma disputa, né uma inimizade nesse relacionamento, isso não ajuda em nada. [...] a gente constrói essa harmonia, constrói essa leveza que eu acho que é uma coisa que Paulo Freire fala. [Po2 - F]

[...] a ideia realmente dele enxergar o ser humano, eu acho que como a gente aprendeu também a enxergar que ele é capaz. [...] Eu vejo que eu tenho é um pouquinho desse cuidado que ele tem de ver o outro. Apesar de às vezes eu falo assim: "gente eu sou muito rígida com os meninos" [...]. [P07 - F]

Demarcamos a lembrança de P02: "uma relação de superioridade, uma relação de imposição". A professora P02 reconhece que a relação educador-educando não pode forjar-se no autoritarismo, em que o estudante é submisso e inferior ao professor. Pelo contrário: ela reconhece a necessidade de pautar a relação entre os sujeitos no amor. A amorosidade é um conceito que percorre toda obra freireana, numa postura recorrente de respeito "com" o outro e de fundamental importância na prática educativa, além de também ser uma das condições do diálogo: "é preciso juntar à humildade com que a professora atua e se relaciona com seus alunos, uma outra qualidade, a amorosidade, sem a qual seu trabalho perde o significado. E amorosidade não apenas aos alunos, mas ao próprio processo de ensinar" (FREIRE, 2012, p. 134). Competência técnica e amorosidade não se dissociam na prática educativa do professor segundo a percepção freireana, pois "só os mal-amados e as mal-amadas entendem a atividade docente como um quefazer de insensíveis, de tal maneira cheios de racionalismo que se esvaziam de vida, de emoção, de sentimentos" (FREIRE, 2012, p. 181-182).

A professora P07 parece se questionar e por em dúvida sua prática ("gente eu sou muito rígida com os meninos"), não sabendo caracterizá-la: se uma postura "autoritária" ou "de autoridade", mas ao mesmo tempo tem na "fé" nos estudantes um elemento que se aproxima de Freire: "enxergar que ele é capaz. [...] Cuidado que ele tem de ver o outro". A "fé" em Paulo Freire expressa-se como uma aposta nos homens e nas mulheres de modificar o mundo ao se libertar das condições de opressão, sendo ainda um elemento preponderante para a relação dialógica verdadeira: "Não há também diálogo se não há uma intensa fé nos homens. Fé no seu poder de fazer e de refazer. De criar e recriar" (FREIRE, 2013, p. 112). 
Nas lembranças dos professores e professoras também emerge a necessidade de superação da "educação bancária" criticada por Freire, avançando rumo a uma postura mais dialógica e democrática na prática da "dodiscência", conforme já descrito anteriormente. É reconhecida a necessidade dos estudantes da EJA participarem da construção do próprio conhecimento, em detrimento de "simplesmente enfiar-lhes um conteúdo" (P01) ou "colocar as coisas [conteúdos] para as pessoas [estudantes] simplesmente guardarem" (P10):

[...] eu acho que são os pensamentos que nós devemos seguir, no sentido de que [...] a gente não coloca as coisas para as pessoas e simplesmente elas guardam e ficam para elas, não é

assim. Então nós, enquanto educadores, nós somos os mediadores apenas. Então o conhecimento, todos nós temos e para o adulto é diferente, para o adulto é melhor ainda. [...] ao longo da minha carreira o que eu aprendi com os meus alunos somam às vezes muito mais do que eu aprendi dentro da universidade, com relação ao que é prática. Então acho que essa construção do conhecimento, ela é de cada um; ela já existe no adulto, e nós apenas somos os mediadores. [P10 - F]

O ato de conhecer, sob a ótica de alguns professores, envolve a construção coletiva e compartilhada e a prática do "diálogo", na qual os estudantes podem contribuir com seus "saberes de experiência feito", além de ser possível também ensinar. Tal postura vai ao encontro da "Pedagogia do oprimido" de Freire:

o educador já não é o que apenas educa, mas o que, enquanto educa, é
educado, em diálogo com o educando que, ao ser educado, também educa.
Ambos, assim, se tornam sujeitos do processo em que crescem juntos. [...] Os
homens se educam em comunhão, mediatizados pelo mundo. Mediatizados
pelos objetos cognoscíveis que, na prática 'bancária', são possuídos pelo
educador que os descreve ou os deposita nos educandos passivos (FREIRE, 2013,
p. 95-96).

O autor destaca que "não há saber nem ignorância absoluta" (FREIRE, 1994, p. 29) e embora valorize o "saber de experiência feito" do estudante, Freire não o "supervaloriza" em detrimento dos saberes sistematizados:

O que proponho é um trabalho pedagógico que, a partir do conhecimento que o aluno traz, que é uma expressão da classe social à qual os educandos pertencem, haja uma superação do mesmo, não no sentido de anular esse conhecimento ou de sobrepor um conhecimento a outro. O que se propõe é que o conhecimento com o qual se trabalha na escola seja relevante e significativo para a formação do educando (FREIRE, 1991, p. 83).

A realidade concreta dos estudantes também foi uma lembrança dos professores e professoras, a qual é atribuída a Freire:

[...] um grande pensador, inclusive, a gente tem que valorizar os nossos [...]. E eu acho que ele entrou muito dentro desse contexto da EJA, da realidade em si, por isso eu acho que ele casa realmente com a educação de jovens e adultos, nesse contexto porque a fala dele vai muito dentro do que a gente tem nessa categoria, nessa modalidade de ensino. [P04 - M]

[...] eu vejo que é muito dele toda vez que eu observo que a educação e a forma de você abordar os conteúdos ela tem que estar inserida dentro do contexto social do educando. A realidade social dele. Então eu trago para mim isso. Eu repito, não sei se eu posso atribuir isso 
aí a ele, ao Paulo Freire, mas toda vez que eu ouço esse tipo de argumento, que você tem que trabalhar dentro da realidade social do aluno, sociocultural do aluno, eu atribuo esse tipo de informação a ele. Trocando em miúdo é como se você tentasse falar de caviar em uma realidade onde o pessoal só come feijão. [P08 - M]

O pensamento de Paulo Freire que mais me chama atenção é aquela educação que alcança o aluno, não aquela educação que exclui o aluno né. É aquela educação que vai alcançar o aluno na sua totalidade, a gente sabe que é difícil, porém esse pensamento me chama atenção.

$$
[\ldots][\text { Pog - F] }
$$

Destacamos o trecho "ele entrou muito dentro desse contexto da EJA, da realidade em si" (P04); "tem que estar inserida dentro do contexto social do educando. A realidade social dele" (Po8); “é aquela educação que alcança o aluno, [...] É aquela educação que vai alcançar o aluno na sua totalidade" (Pog). Assim, nas lembranças freireanas dos professores é reconhecida a necessidade da prática educativa se dar junto ao contexto dos estudantes da EJA, ao seu pertencimento de classe. Ao reconhecer sua concretude, também se problematiza a prática social dos sujeitos. Essa educação, com viés também libertador da condição opressora, "não pode ser a do depósito de conteúdos, mas a da problematização dos homens em suas relações com o mundo" (FREIRE, 2013, p. 94). Nesta pedagogia, que também promove a conscientização crítica dos sujeitos, acentua-se "a problematização contínua das situações existenciais dos educandos [...]. Quanto mais progride a problematização, mais penetram os sujeitos na essência do objeto problematizado e mais capazes são de 'desvelar' esta essência" (FREIRE, 2016, p. 145).

Duas professoras trazem lembranças que se relacionam aos "temas geradores" freireanos: a professora P03 menciona os "três momentos pedagógicos":

[...] eu acredito que seja dele aquela ideia de, do estudo, do aprendizado por armazenamento de informações, do diálogo com aluno. [...] eu estou iniciando uma leitura sobre ela que é os momentos pedagógicos. [...] Seriam três momentos pedagógicos que trata de uma abordagem mais investigativa, problematizada, construção do conhecimento então eu acho que essas teorias tem haver com a proposta dele. [P03 - F]

A menção de P03 se refere à denominada "Abordagem Temática" desenvolvida por Demétrio Delizoicov e colaboradores segundo a perspectiva dos Temas Geradores de Paulo Freire ${ }^{15}$. A professora P05 faz menção ao uso de "palavras-chave" na prática educativa com os estudantes, aproximando do entendimento destes:

[...] a gente na educação de jovens e adultos tinha grupos de estudos, [...] a gente estudava sobre Paulo Freire. Eu só lembro de Paulo Freire, a gente... ele usa muitas palavras chaves para a gente estar trabalhando com os meninos para chega a determinado assunto no entendimento deles. [P05 - F]

Supõe-se que tal lembrança também remeta à investigação temática sugerida por Paulo Freire. Segundo o "método" freireano, que inicialmente foi trabalhado na

\footnotetext{
${ }^{15}$ Sugere-se a leitura de: DELIZOICOV, D.; ANGOTTI, J. A. e PERNAMBUCO, M. M. C. A. Ensino de Ciências: Fundamentos e Métodos. São Paulo: Cortez, 2002.
} 


\section{-Revista de Iniciação à Docência, v.6 , n. 2, 2021- \\ Publicação: dezembro, 2021 - ISSN 2525-4332}

alfabetização de adultos, mas depois difundido em outros níveis/etapas da escolarização, há uma investigação de temas que possuam "sentidos", que sejam "concretos" junto aos contextos sociais dos educandos e educandas, tornando a abordagem dos conteúdos significativos e contextualizados com a existência dos estudantes. Esta aproximação junto ao universo temático dos estudantes também é uma prerrogativa do diálogo e direciona o movimento de problematização:

Esta investigação implica, necessariamente, uma metodologia que não pode contradizer a dialogicidade da educação libertadora. Daí que seja igualmente dialógica. Daí que, conscientizadora também, proporcione, ao mesmo tempo, a apreensão dos "temas geradores" e a tomada de consciência dos indivíduos em torno dos mesmos (FREIRE, 2013, p. 121)

O professor Po6 traz uma lembrança de Freire associando-o ao denominado Construtivismo:

[...] Eu tive 6 meses de didática, [...] foram apresentados para gente conteúdos em relação à Paulo Freire, em relação ao Vygotsky, relação ao próprio construtivismo pregado pelos dois entendeu. $O$ meu conhecimento com relação ao construtivismo ele é raso, [...] mas eu identifico um pouco com a escola [construtivista]. A partir do momento que eu estava falando de trabalhar como modelo que seja palpável, de trabalhar como modelo que seja visível que eu possa perceber pelos meus sentidos automaticamente eu tô trabalhando como modelo construtivista. [P06 - M]

Cabe a tentativa de problematizá-lo como uma teoria de aprendizagem e "aproximá-lo" dos pressupostos freireanos. Para Chakur (2015) o termo construtivismo encontra-se esvaziado de sentido no campo educacional, pois a "construção" do conhecimento perpassa a produção teórica de diferentes autores, mas com diferentes sentidos. Logo, não se pode falar em "construtivismo" no singular, mas de "construtivismos". Carretero (2002, p. 10) demarca o conceito de construtivismo a partir da ideia de que "o indivíduo [...] não é um mero produto do ambiente nem um simples resultado de suas disposições internas, mas sim [...] resultado da interação entre esses dois fatores. [...] O conhecimento não é uma cópia da realidade, mas, sim, uma construção do ser humano". De acordo com Gadotti (1997) Paulo Freire se enquadra no que se denomina de "construtivismo crítico", sendo o ato de conhecer uma construção e uma descoberta, visando à transformação. Até mesmo Paulo Freire, em uma entrevista disponível na internet ${ }^{16}$ afirma ter dado contribuições à estruturação do que se vem chamando de construtivismo no país. De fato, Freire também considera a "construção" do conhecimento como uma produção social. Também se pauta pela concepção de inacabamento dos homens e mulheres, os quais se inserindo criticamente na realidade, numa prática dialógica e exercendo a liberdade, são capazes de conhecer e re-conhecer infinitamente, visando a transformação e reinvenção do mundo na história, que é uma "possibilidade" e não um determinismo (FREIRE, 2013).

\footnotetext{
${ }^{16}$ Registro em vídeo da participação de Paulo Freire numa atividade da Cooperativa Educacional de São Paulo, em 1991. Disponível em: https://youtu.be/I1U8IGOqopw (PARTE 01) e https://youtu.be/Von4bmau7A4 (PARTE 02)
} 


\section{-Revista de Iniciação à Docência, v.6 , n. 2, 2021- Publicação: dezembro, 2021 - ISSN 2525-4332}

A partir das lembranças freireanas que os professores e professoras da EJA buscaram em seus movimentos de formação docente, podemos então sistematizar e sumarizar as principais ideias e/ou conceitos chave que corroboram os pressupostos de Paulo Freire: liberdade-autoridade e rigorosidade-disciplina em relação com a educação libertadora; educação bancária e autoritarismo; fé e amorosidade como condições do diálogo; o ato de conhecer, a construção do conhecimento e a prática da dodiscência; a problematização da realidade social concreta dos estudantes e suas relações com o saber de experiência feito e com a contextualização; os temas geradores e a investigação temática; a conscientização crítica. Houve ainda a tentativa de "enquadramento" de Freire como um construtivista.

É importante frisar que os conceitos-chave e/ou ideias de Paulo Freire não existem isoladas em si mesmas, estando em permanentes e imbricadas interconexões. Diante disto, concordamos com Romão (2014) quanto à perspectiva de que empreender um estudo teórico da obra de Freire, extraindo conceitos-chave, concepções e ideias e ser capaz de ressignificá-las e/ou reinventá-las no contexto histórico atual e diante dos desafios que se apresentam em cada momento não é tarefa fácil. Reiteramos que Paulo Freire não pode ser seguido como um "guia metodológico" ou reduzido a um slogan, mas recriando seus princípios teóricos. Perante o pedido do próprio autor para não ser copiado, mas reinventado, torna-se necessário refazê-lo nos tempos, espaços e contextos históricos distintos.

Neste momento de síntese, é prudente resgatarmos a postura de Esquinsani (2016) a partir de seus achados de pesquisa. Não se pode afirmar que, mesmo diante da citação de conceitos-chave e/ou ideias pertencentes à produção teórica de Paulo Freire por quase a totalidade de professore(a)s entrevistados, houve uma apropriação teórica consistente e consciente dos pressupostos freireanos e que estes, sendo apreendidos em sua essência e radicalidade, de fato, teve/têm influência na prática educativa que exercem junto aos educandos e educandas da EJA. Assim, sugere-se que essa apropriação teórica possa ainda ter traços de certo "dogmatismo" frente ao autor e/ou esvaziamento de suas ideias, as quais podem ter sido citadas por um suposto "modismo" e/ou uso de "clichês" do autor ainda presente no discurso educacional. Não se pode afirmar que as "lembranças freireanas" dos docentes entrevistados coadunam com a necessária "coerência" freireana, uma das principais ideias que também perpassa toda a obra do autor. Para Freire (2020c, p. 101) "a coerência entre o que digo, o que escrevo e o que faço" é um testemunho ético e decente dos professores e professoras em suas práticas educativas.

Este estudo se propôs a contextualizar seu legado teórico e empreender reflexões no campo da formação de professores da EJA a partir das lembranças das ideias de Paulo Freire de sujeitos que "falam de dentro" da realidade concreta das instituições escolares da modalidade. Esperamos que as ponderações aqui realizadas deem suporte para o resgate da visibilidade da EJA como um espaço escolar institucionalizado que possibilite 


\section{-Revista de Iniciação à Docência, v.6 , n. 2, 2021- \\ Publicação: dezembro, 2021 - ISSN 2525-4332}

aos sujeitos educandos e educandas alcançarem sua escolarização básica completa, tantas vezes negada ao longo de suas trajetórias. Cassab (2019, p. 15) apresenta que "o trabalho na Educação de Jovens e Adultos é o terreno desassossegado da resistência". Então, resistamos e "esperancemos" por uma EJA que conquiste e tenha um espaço consolidado no campo das políticas educacionais, comprometendo-se a reverter o quadro de desigualdades sociais.

\section{Considerações finais}

Neste início da terceira década do século XXI, vivemos tempos difíceis A pandemia de COVID-19 persiste no Brasil e no mundo, trazendo duros impactos para a sociedade, principalmente no que se refere ao aumento das desigualdades sociais. Enquanto isso, os "ventos políticos" que sopram em nosso país também não são nada favoráveis. A crise sanitária persiste, bem como a ambiental e os índices de desemprego, miséria e fome avançam negativamente. No campo educacional, o desmonte da educação pública brasileira também progride. Estamos mergulhados numa crise de retrocessos e perda de direitos conquistados historicamente com muita luta. Mas neste cenário, cabe relembrarmos a famosa citação de Darcy Ribeiro"7: "a crise da educação no Brasil não é uma crise; é um projeto". Concordando com esta perspectiva, o "projeto" instalado vai desconstruindo a escola pública brasileira, já tão fragilizada historicamente. Quanto à EJA, que historicamente ocupa um lugar de exclusão, vai sofrendo um "apagamento" (HEBERLEIN, 2020): nas políticas educacionais, no financiamento, nas orientações curriculares e nas diretrizes para a formação de professores para a modalidade, a qual é objeto de reflexão neste estudo.

Diante desta tentativa de "apagamento" da EJA em nosso país, buscamos neste trabalho uma "luz" no legado freireano a fim de, a partir de seus pressupostos teóricos, iluminar o contexto atual e empreender reflexões sobre a formação de professores para a modalidade, re-pensando-a e vislumbrando sua reinvenção, conforme orienta Freire. Este movimento se deu a partir de entrevistas que promoveram o resgate das lembranças de Paulo Freire que se impregnaram no processo formativo (inicial e/ou continuado) de professores e professoras da EJA de instituições escolares goianas que oferecem prioritariamente a modalidade. A partir das lembranças resgatadas, foi possível perceber que o legado freireano se faz presente e pode constituir-se como um suporte à prática docente na EJA. Vários conceitos-chave e/ou ideias de Paulo Freire emergiram nas lembranças resgatadas pelos professores e professoras.

A partir desta análise prévia, acreditamos ainda ser possível que o legado freireano se constitua como um referencial válido, legítimo e atual no campo da formação de professores para atuação na EJA. As "lembranças freireanas" que os professores e professoras carregam podem de fato se materializarem em práticas educativas que

\footnotetext{
${ }^{17}$ Proferida numa palestra intitulada "Sobre o óbvio" em um Congresso da SBPC em 1977.
} 
tenham por horizonte a realidade social concreta dos educandos e educandas da modalidade. De acordo com Giovanetti (2011) não podemos perder de vista duas marcas identitárias para o trabalho educativo na EJA: a origem social dos estudantes e uma educação pautada na intencionalidade de contribuir para o processo de mudança social, as quais são perspectivas que corroboram os pressupostos freireanos.

Concordamos com Arroyo (2006) quanto ao desafio de traçar um perfil para o professor da EJA, pois este ainda está em construção, sendo necessário "inventá-lo". Mas se existe um "perfil" de professor e professora na EJA que perseguimos, acreditamos que o resgate do referencial freireano e sua reinvenção diante dos tempos-espaços históricos poderá possibilitar "moldar" permanentemente profissionais docentes compromissados com o resgate do direito à educação na EJA e cumprindo sua função social, quer seja possibilitar o acesso aos conhecimentos sistematizados e acumulados historicamente pela humanidade, socializando-os na escola, mas que também considere e parta dos "saberes de experiência feito" a fim de superá-los.

\section{Referências}

ARROYO, M. Educação de jovens-adultos: um campo de direitos e de responsabilidade pública. In. SOARES, Leôncio; GIOVANETTI, Maria. GOMES, Nilma; (org). Diálogo na educação de jovens e adultos. 4.ed. Belo horizonte: autêntica, 2011, p. 243-254.

ARROYO, M. Formar educadoras e educadores de jovens e adultos. In: SOARES, Leôncio (Org.) Formação de educadores de jovens e adultos. Belo Horizonte: Autêntica/SECADMEC/UNESCO, 2006, p. 17-32.

BRASIL. Resolução CNE/CP n.2, de 20 de dezembro de 2019. Define as diretrizes curriculares nacionais para a formação inicial de professores para a educação básica e institui a base nacional comum para a formação inicial de professores da educação básica (BNC-Formação), 2019. Disponível em: https://bit.ly/3BluEKF Acesso em: 12 ago. 2021.

BRASIL. Secretaria de Educação Básica. Base nacional comum curricular: educação é a base. Brasília, DF: MEC, 2017. Disponível em: https://bit.ly/3uOCnhK Acesso em: 12 ago. 2021.

CARRETERO, M. Construtivismo e educação. Porto Alegre: Artes Médicas, 2002.

CASSAB, M. Conhecimento e Docência: Caminhos Cruzados na Educação de Jovens e Adultos. Prefácio. In: NICODEMOS, Alessandra. Conhecimento e docência: Caminhos Cruzados na Educação de Jovens e Adultos. 1. ed. Jundiaí (SP): Paco Editorial, 2020.

CHAKUR, C.R.S.L. A desconstrução do construtivismo na educação: crenças e equívocos de professores, autores e críticos [online]. São Paulo: Editora UNESP, 2015.

DOURADO, L. F.; OLIVEIRA, J. F.. A qualidade da educação: perspectivas e desafios. Cadernos Cedes, Campinas, v. 29, n. 78, p. 201-215, maio/ago. 2009.

ESQUINSANI, R. S. S. Entre a dogmatização e o esquecimento: paulo freire e a formação inicial de professores. Revista Inter Ação, [S. I.], v. 41, n. 1, p. 233-246, 2016. 
FREIRE, P. A educação na cidade. São Paulo: Cortez, 1991.

FREIRE, P. Conscientização. 1. ed. São Paulo: Cortez, 2016.

FREIRE, P. Educação e mudança. 20 ed. Rio de Janeiro: Paz e Terra, 1994.

FREIRE, P. Pedagogia da autonomia: saberes necessários à prática educativa. 63 ed., São Paulo: Paz e Terra (Coleção Leitura), 2020c.

FREIRE, P. Pedagogia da esperança: um reencontro com a pedagogia do oprimido. 17. ed. Rio de Janeiro: Paz e Terra, 2011.

FREIRE, P. Pedagogia da indignação. 1. ed. São Paulo, Editora Unesp, 2014.

FREIRE, P. Pedagogia da tolerância. 7. ed. Rio de Janeiro: Paz e Terra, $2020 a$.

FREIRE, P. Pedagogia do oprimido. 54. ed. Rio de Janeiro: Paz e Terra, 2013.

FREIRE, P. Política e educação. 6. ed. Rio de Janeiro: Paz e Terra, $2020 \mathrm{~b}$.

FREIRE, P. Professora sim, tia não: cartas a quem ousa ensinar. 23. ed. Rio de Janeiro: Civilização brasileira, 2012.

FREIRE, P. Profissão professor. Série Raízes e Asas (Vídeo). CENPEC - Centro de Estudos e Pesquisas em Educação. São Paulo: 1995.

FREIRE, P.; BETTO, F. Essa escola chamada vida: depoimentos ao repórter Ricardo Kotscho. São Paulo, Ática, 1985.

FREIRE, P.; FAUNDEZ, A. Por uma pedagogia da pergunta. 9. Ed. Rio de Janeiro: Paz e Terra, 2019.

FREIRE, P.; SHOR, I. Medo e ousadia: o cotidiano do professor. Rio de Janeiro: Paz e Terra, 1987.

GADOTTI, M. Lições de Freire. Revista da Faculdade de Educação, São Paulo, v. 23, n. 1-2, Jan/ Dez, 1997.

GHIGGI, G. Paulo Freire e a revivificação da Educação Popular. Educação, Porto Alegre, v. 33, n. 2, p. 111-118, maio/ago. 2010.

GIOVANETTI, M. A. G. C. A formação dos educadores na EJA: o legado da Educação Popular. In. SOARES, Leôncio; GIOVANETTI, Maria. GOMES, Nilma; (org). Diálogo na educação de jovens e adultos. 4.ed. Belo horizonte: autêntica, 2011, p. 243-254.

HEBERLEIN, M. C. T. A constituição discursiva da educação de jovens e adultos no Instituto Federal de Goiás a partir das representações de professores de línguas estrangeiras, alunos, coordenadores e documentos institucionais. 2020. Tese (Programa de Pós-Graduação em Letras e Linguística), Universidade Federal de Goiás, Faculdade de Letras (FL), Goiânia, 2020.

LOMBARDI, J. C. Reflexões sobre educação e ensino na obra de Marx e Engels. Campinas, SP: Tese (livre docência) - Universidade Estadual de Campinas, Faculdade de Educação, [s.n.], 2010.

MACHADO, M. M. Formação de professores para EJA: uma perspectiva de mudança. Retratos da escola, Brasília, v. 2, p.161-173, jan/dez 2008. 
PARANHOS, R. de D.; AVELAR, L. M. de .; MASCIOLI, C. da C. K.; GUIMARÃES, S. S. M. A educação de jovens e adultos no contexto da formação de professores de Biologia. Revista docência do ensino superior, Belo Horizonte, v. 10, p. 1-19, 2020.

ROMÃO, J. E. Paulo Freire e a educação de jovens e adultos. EJA em debate, Florianópolis, ano 3, n. 4. jul. 2014.

SAUL, A. M.; SAUL, A. Contribuições de Paulo Freire para a formação de educadores: fundamentos e práticas de um paradigma contra-hegemônico. Educar em Revista, Curitiba, n. 61, p. 19-35, jul./set. 2016.

SAVIANI, D. Crise estrutural, conjuntura nacional, coronavírus e educação - o desmonte da educação nacional. Revista Exitus, [S. I.], v. 10, n. 1, 2020.

SCOCUGLIA, A. C. Paulo Freire, 100 anos: um educador do presente e do futuro. [livro eletrônico]. Campina Grande: EDUEPB, 2021.

SOARES, L. (org.) Formação de educadores de jovens e adultos. Belo Horizonte: Autêntica/ SECAD/MEC/UNESCO, 2006.

SOARES, L.; GIOVANNETTI, M. A. (Org.). Diálogos na educação de Jovens e adultos. 4. ed. Belo Horizonte: Autêntica, 2011.

Recebido: 13.08.2021

Aprovado: 02.11.2021 